\title{
Lamellar Pattern
}

National Cancer Institute

\section{Source}

National Cancer Institute. Lamellar Pattern. NCI Thesaurus. Code C43626.

Having an appearance of thin plate-like structures. 